\title{
Reflecting on Straight Talk on Trade
}

\author{
Alvaro Santos \\ Georgetown University Law Center, asantos@law.georgetown.edu
}

This paper can be downloaded free of charge from:

https://scholarship.law.georgetown.edu/facpub/2232

https://ssrn.com/abstract=3538469

Alvaro Santos, Reflecting on Straight Talk on Trade, in World Trade and Investment Law Reimagined: A Progressive Agenda for an Inclusive Globalization 47 (Alvaro Santos, Chantal Thomas \& David Trubek eds., London: Anthem Press 2019).

This open-access article is brought to you by the Georgetown Law Library. Posted with permission of the author. Follow this and additional works at: https://scholarship.law.georgetown.edu/facpub

Part of the International Trade Law Commons, and the Law and Economics Commons 


\section{REFLECTING ON STRAIGHT TALK ON TRADE Alvaro Santos}

It has been a treat to read Dani Rodrik's book. I have been an avid reader of his work for a while, and it has been influential in my own thinking, teaching and research. For some time, I have been interested in how critiques of mainstream economics can dialogue with critical legal thinking, and how they might benefit each other. ${ }^{1}$ The goal is to explore how economic and legal thought can join forces to imagine alternatives to the existing institutional form globalization has taken. I offer my comments in the spirit of that exploration. A question that motivates this essay is: What insights can we offer from legal scholarship that Rodrik could take on board and put to good use?

Rodrik is an economist, but he might as well have been a lawyer in the way he builds his argument and anticipates counterarguments. I mean that as a compliment. As a bonus, he delivers the punch line with humor and grace. In his book I recognized several of the many contributions Rodrik has made: his argument for policy space and revitalization of industrial policy, the globalization trilemma, the idea and process of growth diagnostics and the idea of premature deindustrialization and the powerful challenge it presents to developing countries.

I also recognized familiar characters: hyperglobalization, the globalization cheerleaders, the economics professor who speaks with nuance and qualifications when talking about the benefits of trade to graduate students in the classroom but is completely simplistic and even disingenuous when talking to the media. Let's call this character the "two-faced" economist. The book has many valuable ideas, but I want to focus on three themes: (1) the plurality of models, (2) fair trade and (3) the agenda for the nation-state.

\section{A World of Many Models}

Reading the chapters "Economists and Their Models" and "The Perils of Economic Consensus," I thought they could be called "Saving Economics from Economists." Rodrik takes the two-faced economists to task for contributing to a decrease in the credibility of the discipline and even to the globalization backlash. Arguing for trade liberalization as an unqualified policy program had begun to tarnish the discipline that so unconditionally promoted it in the face of economic malaise and unfulfilled expectations. Instead of recognizing that the case for trade was complex and that there were good reasons to allow for trade barriers in some cases, and for slowing down in others, trade economists generally peddled for ever increasing liberalization as if it was going to benefit all. ${ }^{2}$

Furthermore, by dismissing the critiques of trade liberalization, economists reduced the scope of the public debate and made globalization look more coherent and institutionally fixed than was warranted, thus contributing to the backlash. Economists shaded their arguments, afraid of giving ammunition to the protectionist "barbarians," but by doing so they reinforced the idea that there

\footnotetext{
${ }^{1}$ See, e.g., Alvaro Santos, “Carving Out Policy Autonomy for Developing Countries in the World Trade Organization: The Experience of Brazil and Mexico," Virginia Journal of International Law 52 (2012): 551-632.

2 See Dani Rodrik, Straight Talk on Trade: Ideas for a Sane World Economy (Princeton, NJ: Princeton University Press, 2018), 114.
} 
was a binary of trade liberalization versus protectionism and that the trade regime could not accommodate important concerns about fairness and distribution. ${ }^{3}$

Now that the political backlash against globalization is set on rolling back trade liberalization and retrenching to economic nationalism, trade economists are less equipped and have less credibility to defend global trade. This becomes evident when the response to the policies of the Trump administration or of the United Kingdom's Brexit seems to focus on defending the global arrangements that existed before this crisis of legitimacy.

Rodrik's rendition of the pluralism of models in economics was fascinating and, again, advanced in the service of highlighting the sophistication, nuance and robust debates in the economics discipline, much of which gets lost when translated to public policy or to the public. His description very much reminded me of the condition of law as a discipline: there is no reigning model or method, but a plurality of them, which are often in competition, sometimes quite vigorously, which makes for a plural legal academy.

In the legal academy, this doesn't necessarily mean robust debate. There is that, to be sure. But sometimes it leads to silos or factions and to insecurity about not having a robust methodology so that we legal scholars often borrow from other social sciences. The freedom of this pluralism can sometimes lead to experimentation and originality that would be difficult to imagine if there was a dominant method. So plurality comes with ambivalence and, I think, is carried both with certain insecurity and as a badge of honor.

Rodrik makes clear that there is often indeterminacy in the models, stating that "economics is really a toolkit with multiple models - each a different, stylized, representation of some aspect of reality."4 There are competing models that lead to different explanations and policy recommendations. Rodrik celebrates this pluralism. The key, and this is what Rodrik is after, is to learn how to choose between competing models. "One's skill as an economic analyst depends on the ability to pick and choose the right model for the situation," 5 something that, he bemoans, economists are not taught to do and the profession doesn't invest much research on. This part of economics is more "craft" than "science." It requires judgment. And he seems to want to push in this direction, perhaps to build a method about how to choose the right model.

As appealing as the project sounds, I am skeptical of the project of developing a method to choose the "right" model. That, it seems to me, presupposes that there is a meta-level standpoint, free from the influence of method, from where we can choose. Reading Rodrik's own account about the situation of his discipline, it seemed to me that there is no neutral perch from which to pick and choose which model would be more useful. No high hill from which to see with clarity which road to follow. The view of the utility of one or another model will be colored by one's own assumptions, that is, by one's own implicit or explicit meta model. And at that level, too, there will be competition and uncertainty.

The parallel experience in legal scholarship might be illustrative. There are also a variety of "models" or approaches to "law," including formalism, legal realism, originalism, law and

\footnotetext{
${ }^{3}$ Ibid., 138.

${ }^{4}$ Ibid., 143.

${ }^{5}$ Ibid.

${ }^{6}$ Ibid., $143-44$.
} 
economics, legal process, critical legal thought, feminist legal theory, critical race theory and so on. These different models or approaches rely on different assumptions and provide a different diagnosis and prescription to a legal problem. The most sophisticated legal actors can deploy different arguments from this or that school to win a case or advocate for a policy proposal. But it would be hard for any lawyer or legal scholar to argue, in all candor, that he or she has chosen the "right" approach for a particular setting. Right for whom? Or for what purpose? It becomes an argument for policy preference and expected outcomes, based on normative assumptions.

In the face of indeterminacy in the legal materials ${ }^{7}$ - of rules, rights, general principles and doctrines - legal scholars and lawyers often seek to ground their position on a higher plane, a constitutional right, for instance. But the Constitution is often vague, and there are competing rights and principles at the constitutional level, too. So scholars have resorted to moral and political theory to ground their position. Only there are competing moral and political theories, too. The point is not to show a hopeless condition of infinite regression but rather to recognize that the choice of method for a given situation is that: a choice. Often a choice between equally plausible options, driven not by what is right but by what the chooser prefers or believes. ${ }^{8}$

Rodrik provides a powerful example of indeterminacy and the existence of competing models in his account of the debate about the Trans-Pacific Partnership (TPP), which he called the "trade numbers game" or "war of trade models." 10 He argues that "neither side's models generate numbers reliable enough on which a case for or against the TPP could be made. Just about the only thing we can say with some certainty is that there would have been gainers and losers."11 Undoubtedly, there is value in debate, and Rodrik argues that competition between models can help clarify where disagreement lies. It can help narrow the space between authors of different ideological bents, as illustrated by Robert Barro and Jason Furman's paper on the potential effects of the recent US tax reform. ${ }^{12}$ This seems entirely plausible but still a long way from coming up with a method that helps one apply the "right" model to a particular context.

What I find most appealing about Rodrik's analysis in this regard, clearly stated in his critique of the trade liberalization cheerleaders, is his call for nuance and modesty, his insistence on the importance of stating assumptions and recognizing qualifications in the analysis, the courage to recognize uncertainty and tentativeness when pressured to give confident and bold answers. So Rodrik invites us to admit the terrain of uncertainty and not knowing, to recognize when we do not know and to admit public responsibility for our decisions and recommendations. Rodrik gives us a powerful image: "It is the neglect of the craft element - aiming to elevate economics' status as science - that occasionally turns it into snake oil.".13

Rodrik's description of the two-faced economist fits nicely with the two-faced lawyer. Despite the experience of pluralism in legal methods, ask any lawyer involved in a case or a regulatory

\footnotetext{
${ }^{7}$ See, e.g., Karl N. Llewellyn, “A Realistic Jurisprudence: The Next Step,” Columbia Law Review 30, no. 4 (1930): 431; Karl N. Llewellyn, "Remarks on the Theory of Appellate Decision and the Rules or Canons about How Statutes Are to Be Construed," Vanderbilt Law Review 3 (1950): 395.

${ }^{8}$ See, e.g., Duncan Kennedy, "The Critique of Rights in Critical Legal Studies," in Left Legalism/Left Critique, eds. Janet Halley and Wendy Brown (Durham, NC: Duke University Press Books, 2002).

${ }^{9}$ Rodrik, Straight Talk on Trade, 123.

${ }^{10} \mathrm{http}: / /$ rodrik.typepad.com/dani rodriks weblog/2015/05/the-war-of-trade-models.html.

${ }_{11}$ Rodrik, Straight Talk on Trade, 126.

${ }^{12}$ https://twitter.com/rodrikdani/status/971731300351700992.

13 Rodrik, Straight Talk on Trade, 145.
} 
decision and he or she will speak in public with absolute certainty about the existence of this or that right solution. Everybody knows, however, that there is likely a plausible counter. Think about the hearings in the nomination ritual for justices in the Supreme Court. The nominees are selected by a president who expects they will vote according to the ruling party preferences on a range of issues. Nominees go through this rite of passage in a completely predictable way, saying that they will only apply the law, not make it; that their role is that of an umpire, not a player; that they will follow precedent and so on.

First-year law students and the informed lay public can tell that what the nominees profess to do is just not possible in the types of cases that reach the Supreme Court. The reason a given nominee is selected is precisely so that he or she can decide cases, according to a liberal or conservative philosophy, with vast implications for the country. Everybody knows, but no one will admit it publicly, least of all the nominee, for whom it would be confirmation hara-kiri. Nobody speaks candidly, perhaps out of fear of the potential damage such overt admission of perspectivism would inflict on the legitimacy of the legal profession.

I perceive a similar, perhaps unstated, preoccupation with the legitimacy of the economics profession, and of its authority, if it admits not knowing. If it recognizes its uncertainty. If it acknowledges that there is no "right" answer or model. Rodrik presents us with an intriguing paradox here in that the more confident and "right" the discipline has pretended to be, the weaker it becomes. If we take this insight seriously, we would need to conclude that this is true, too, for the project of building "an empirical method that helps us apply the right model to the particular context"14 at hand.

\section{Fair Trade and the New Rules for the Global Economy}

One of the most enduring critiques in Rodrik's work has been that trade can undermine the social values and norms that a nation has worked hard to establish. The problem, he argues, is not that trade heightens competition and cheaper imports may displace domestic producers. That is expected of trade. The problem arises when those imports are produced under conditions that would be prohibited or simply not tolerated in the importing country because they go against its fundamental values. Think of basic labor rights, or environmental and health standards. When those imports threaten the viability of domestic norms by creating incentives to water these norms down or else push domestic producers out of business, that competition, Rodrik concludes, is unfair. Thus, he argues that trade barriers are entirely justified to prevent this affront to domestic social norms. In fact, he has proposed the design of trade remedies against "social dumping," such as the increase of tariffs against imports, modeled after antidumping remedies. ${ }^{15}$

Rodrik enshrines these ideas in a set of seven principles or rights to guide the reshaping of globalization. Principle 4 states: "Countries have the right to protect their own regulations and institutions." "So countries should be allowed to impose barriers at the border if imports threaten to undermine their social norms, such as labor rights, financial regulation, environmental protection and so on. This, Rodrik tells us, will in fact strengthen rather than weaken the legitimacy of the trading system. Principle 5 reads: "Countries do not have the right to impose

\footnotetext{
14 Ibid., 143 (emphasis added).

15 Ibid., 231-32.

16 Ibid., 224.
} 
their institutions on others." 17 Rodrik explains that using trade restrictions to "uphold values and regulations at home must be sharply distinguished" from imposing those values on other countries. ${ }^{18}$

Each of these rights sounds great on its own and in the abstract. But from a legal perspective, they are hardly useful guidance once one tries to operationalize them. Why? Because these rights are relational. ${ }^{19}$ Having a right to protect your domestic standard in international trade often does mean imposing it on others. Conversely, having someone else's standard prevail on your market makes your right to protect your own regulation rather hortatory. If two countries have competing rights, one will prevail.

In fact, a lot of the WTO Appellate Body work has centered on trying to adjudicate between different national standards. Consider the Shrimp-Turtle case. ${ }^{20}$ The United States put in place a measure that conditioned market access of shrimp imports to foreign producers adopting essentially the same standard required of US producers, a technology called TED, or turtle exclusionary device. One may ask, Why isn't the United States free to require other countries who want to export to the US market to follow the same standard it requires domestically for its own producers? That is exactly the argument the United States made in that and similar cases. Once again, the United States has the right to protect its own standard. But that means that Malaysia will have to adopt the US standard if it wants to sell in the United States, the biggest shrimp market. And that would probably mean, in practice, that it would change its shrimpfishing practices overall.

Moreover, it is tempting to try to explain this tension away by referring to choice. In this case, Malaysia is free to decide whether it wants to sell shrimp to the US market or not. There is no imposition: Malaysia has the choice to sell or not to sell. While this is formally true, market conditions can be quite coercive so that the idea that there is no imposition is problematic in practice. There is a long tradition in legal scholarship, going back to the legal realists, of pointing to the coercive nature of market relations in contrast to the notion of free markets and free choice by market actors. ${ }^{21}$ If the market was never free from the state, because it was always built on state-sanctioned law, and if it enabled coercive relations, the relevant question was not whether it was free or coercive but what effects did it deliver and whether those results were socially acceptable. Whether a country chooses to adopt another country's standard, or lets the standard be imposed on it, will depend on its alternatives and fallback position. It will depend on how costly it would be to adapt, how important that market is for the exporter and whether it can withstand its loss.

From the point of view of fairness, which animates Rodrik's work in this regard, one may ask: Is the United States imposing a cost on other countries by requiring them to adopt its own standard (Malaysia's point of view)? Or is Malaysia giving a subsidy to its producers or "dumping" by not

\footnotetext{
17 Ibid.

18 Ibid.

${ }^{19}$ See, e.g., Wesley Hohfeld, "Some Fundamental Legal Conceptions as Applied in Legal Reasoning," Yale Law Journal 23, no. 1 (1913).

${ }^{20}$ Appellate Body Report, United States-Import Prohibition of Certain Shrimp and Shrimp Products, WT/DS58/AB/R (October 12, 1998).

${ }^{21}$ Robert L. Hale, "Coercion and Distribution in a Supposedly Non-coercive State," Political Science Quarterly 38 (1923): 470, 471-74, 492-94.
} 
requiring a higher environmental standard (the United States' point of view)? If producers in each country sold only in their own market, there would be no conflict. But as soon as they trade, a conflict may arise. It seems that we cannot resolve this conflict by resorting to the two general rights, or first principles, that Rodrik formulated above.

The idea here is that there is no normal baseline, no neutral way of deciding which should prevail. ${ }^{22}$ From a policy perspective, the decision would depend on what one thinks of the protection of turtles from shrimp trawlers, the incidence of turtle deaths, how altering the standard would affect Malaysian shrimp producers, US shrimp producers, consumers and so on-the kinds of questions Rodrik asks incisively at the domestic level but that may be avoided at the global level by referring to these general principles, which can't provide concrete answers.

Cases like this now abound in the World Trade Organization (WTO). They are not limited to conflicts between big and small economies. In the Beef-Hormones case, ${ }^{23}$ the European Union (EU) banned beef meat produced with hormones, a common practice in the United States, from being sold in its market, alleging potential risks to human health. So the EU has the right to protect its no-beef-hormones standard but does not have the right to impose it on others. But if the trading partner willing to sell to the EU does not "choose" to adopt that standard, there will be no trade between them. The United States sued the EU claiming a violation of the Agreement on the Application of Sanitary and Phytosanitary Measures (SPS). The EU lost the case as it failed to demonstrate, according to the WTO Appellate Body, that the risk assessment, based on scientific evidence concerning the effect of beef hormones on human health, warranted the ban. It became a protracted and acrimonious dispute, involving retaliatory measures by the United States and an ultimate settlement. The result is nothing we could have predicted, or resolved, from reference to Rodrik's two general rights.

Our sense of how those two rights may be balanced when there is conflict would often depend on what is the standard at stake, for example, an environmental standard that protects dolphins from being killed when catching tuna, a labor standard that bans goods produced under slavery-like conditions, an intellectual property standard that protects a lifesaving but expensive drug from being copied, a warning label on cigarette packages and so on. Developing countries have often been suspicious of arguments to enable trade barriers for not conforming to a given standard. They see it as an excuse by rich countries to protect their own producers and undermine poor countries' competitive advantage. This is why they resisted the link between trade and labor standards back in the WTO Singapore Ministerial meeting in $1996 .{ }^{24}$ Perhaps this mistrust, and this resistance, has been a mistake and, in the case of labor rights, a type of self-inflicted harm. For even if the motives of rich countries were self-interested, this may have helped improve labor standards in poor countries in ways that could have been beneficial to them, too. But again, this is a judgment based on the consequences of adopting those standards, not on whether a country has the right to impose its standards on others.

\footnotetext{
${ }^{22}$ See, e.g., Daniel K. Tarullo, "Beyond Normalcy in the Regulation of International Trade," Harvard Law Review 100 (1987): 546; Robert Howse, "From Politics to Technocracy and Back Again: The Fate of the Multilateral Trading System," American Journal of International Law 96 (2002): 94.

${ }^{23}$ Appellate Body Report, EC Measures Concerning Meat and Meat Products (Hormones), WT/DS26/AB/R, WT/DS48/AB/R (February 13, 1998).

${ }^{24}$ See WTO Singapore Ministerial Declaration, WT/MIN(96)/DEC, 36 ILM 218 (December 13, 1996).
} 
Finally, an important question is: Who decides? Given the relational character of rights, even if we wanted to take Rodrik's rights as guiding stars, there will inevitably be conflict. Who will decide these conflicts and how? That's just as important a question as what the rights are. Acute commentators of the WTO have noted the effort of its Appellate Body to grapple with these questions, trying to balance the goal of national regulatory autonomy (preserving one's standard) with the goal to prevent discriminatory trade measures (imposing one's standard), moving gradually away from the deep-integration, neoliberal ethos behind the founding of the WTO. ${ }^{25}$ One may rightly quarrel with the current balance struck by the Appellate Body or with the criteria used, perhaps still too lopsided in favor of trade liberalization. But it is an effort to try to reconcile competing rights or interests between states and consider the consequences. No doubt the system is a far cry from inclusiveness, political deliberation and participation of relevant actors, something Howse and Nikolaidis have pushed for in their argument for "global subsidiarity" or "global trade ethics." "26 The point here is that we may need to spend considerable effort in redesigning the global institutions for decision making, be it the WTO or elsewhere, as an alternative to devolution to the nation-state.

\section{The Return of the Nation-State}

Rodrik turns his analysis to the nation-state as the key agent in globalization. He notes that "political communities are organized largely within nation-states and are likely to remain so for the foreseeable future." ${ }^{27}$ His work has laid down a program for both rich countries (fair trade, measures to address inequality and distribution) and for developing countries (policy space for growth policies). I am very sympathetic to this project. But I also see some costs of this frame or "model" that would be worth considering.

I found his discussion in chapter 7, "Economists, Politics and Ideas," fascinating. It presents a challenge to "determinism," often expressed in the role that interests play in the analysis of political economists. "In truth," he claims, "we don't have 'interests.' We have ideas about what our interests are." 28 We have ideas about our preferences, our selves, and how we optimize those preferences. But those ideas are not fixed. They are not necessary. Our interests, how we, or any group - the ruling class, the rich-"see" what our interests are is a construction based on ideas. And these ideas are subject to change. This insight opens up the door for reimagining. For plasticity rather than determinacy. For understanding the contingency of our interests and their ability to change. For realizing, too, that the institutional expression of those mutable interests is equally amenable to change. This is a very valuable insight.

But so is the nation-state: an idea. Rodrik seems to acknowledge this when he proposes a "normative case for the nation-state." 29 His is a refreshing and thoughtful counter to the global governance mantra. ${ }^{30}$ Rodrik argues that the nation-state "remains the main determinant of the global distribution of income, the primary locus of market-supporting institutions, and the chief

\footnotetext{
25 See, e.g., Robert Howse, “The World Trade Organization 20 Years On: Global Governance by Judiciary," European Journal of International Law 27, no. 1 (2016): 9; Andrew Lang, World Trade Law After Neoliberalism: Reimagining the Global Economic Order (Oxford: Oxford University Press, 2011).

${ }^{26}$ Robert Howse and Kalypso Nikolaidis, "Toward a Global Ethics of Trade Governance: Subsidiarity Writ Large," Law and Contemporary Problems 79 (2016): 259.

${ }^{27}$ Rodrik, Straight Talk on Trade, 223.

${ }^{28}$ Ibid., 163 (emphasis in the original).

${ }^{29}$ Ibid., 24.

${ }^{30}$ Ibid., 16.
} 
repository of personal attachments and affiliations." ${ }^{31}$ It is an argument for heterogeneity, and for experimentation and competition in institutional arrangements that respond to the particular context of each nation-state. Yet Rodrik's support for the nation-state sometimes seems descriptive and practical, based on geography and space, on the convenience of already demarcated administrative and political jurisdictions called states. ${ }^{32}$ On the expediency of reality as we know it rather than in the normative desirability of his project.

Rodrik's narrative of the inescapability of the nation-state is a powerful one, important for the normative project he has in mind. His advocacy for the nation-state anticipates the achievement of greater economic prosperity at the national and thus global level. But it also seems informed by an antielitist sensibility based on a hope for a more democratic distribution of income and opportunity. In Has Globalization Gone Too Far?, ${ }^{33}$ Rodrik was already pointing to the widening cleavage within nation-states between a mobile, highly skilled professional class and the rest; an elite that increasingly saw its interests detached from the fortune of its nation-state; a class of people that saved and invested their money abroad, sent their children to study overseas, traveled and vacationed elsewhere. In sum, a well-off, cosmopolitan, mobile class that had benefited from globalization and did not see their future and their lot aligned with the interests of their nation-state, or that even perceived their own interests to be in conflict with their nation's economic efforts. In short, an economic integration that was engendering social disintegration and an unwillingness to cooperate and solve conflicts through the political process.

We have become used to thinking of big multinational corporations as stateless and unmoored. So are the wealthy and many highly skilled professionals. They often move around and change allegiance, depending on their interests or, I should say, the ideas they have about their interests. And this can be true, too, of a country's political elite. Consider criticisms of the Greek policy elite in charge of negotiating the bailout, seemingly more interested in pleasing and appeasing the European technocrats than their own people. Or the increasing number of Mexico's policy, economic and cultural elite, for whom the United States is a second home. Rodrik's project reads as a push for closing that widening gap and reasserting the power and autonomy of the state so that the economic elites, once again, see their interests as coinciding with their nation's to promote greater welfare at home.

Rodrik's project is a plea to reassert the nation-state as the main site for governance and political deliberation. The state is, or is becoming again, the most powerful idea of an organized political community today. No doubt about that. Why not take advantage of its gears and levers to advance greater welfare? Rodrik is, of course, aware of the horrors of the nation-state, past and present. Indeed, the current backlash against globalization has been fueled by nationalist movements, discontent with economic dislocation, and the erosion of national identity. So far, that nationalist project, be it in the United States or any of the EU countries, has shown an ugly face.

So the point is not that the nation-state is a factum, but that Rodrik thinks it is desirable. That he thinks the greater promise for economic prosperity and meaningful political engagement lies within the nation-state. And that a globalization that is predicated on the welfare of these various

\footnotetext{
31 Ibid., 19.

32 Ibid., 24.

33 Dani Rodrik, Has Globalization Gone Too Far? (Washington, DC: Peterson Institute for International Economics, 1999), 69-70.
} 
political communities, accepting their varied choices and speed, would be a better one. The autonomy he would like to carve out for nation-states from hyperglobalization is also one designed exclusively for nation-states with democratic processes and values. There, he is no shy of value imposition on national autonomy. ${ }^{34}$ It is an ambitious normative project, and it would be better to fully recognize it as such. Not because the state exists; many other ideas about organizing political communities exist (and others can be imagined). But because Rodrik probably thinks that the risks of emboldening the nation-state, of which there are many, are outweighed by the economic and social benefits it can bring about. Or because the types of lives we can lead under a more autonomous state would be more thriving and fulfilling, shielded from the fast winds of economic insecurity and more engaged in the decisions that determine our future.

Rodrik posits that "we have to live in the world we have, with all its political divisions, and not the world we wish we had. The best way to serve global interests is to live up to our responsibilities within the political institutions that matter: those that exist, within national borders." 35 Again, although this sounds like a wonderful adage of pragmatic reason, it strikes me more like a powerful argument of normative vision. One needs to be reminded that many of the critiques of global governance in terms of "democratic deficit, lack of legitimacy, and loss of voice and accountability" 36 are often true of democratic politics in the nation-state, too. For many excluded or disenfranchised groups within the nation-state, international governance mechanisms became important for voice and inclusion, whether in questions of civil and political rights or of the impact of grand development projects in their local communities.

Rodrik concludes by asking "Who needs the nation-state? We all do." 37 Well, there will be losers too, perhaps the globalist cosmopolitan class that has so far been the winner of hyperglobalization. Or the financial and corporate interests that have handsomely influenced and benefited from existing global rules and incentives. They may not need Rodrik's version of the nation-state. But the world Rodrik depicts would seem overall much saner. While I am very sympathetic to his vision, I profess a certain ambivalence about the nation-state. I can see both its beneficial and ruinous faces. At a time where the globalization backlash throws into question the assumptions and institutions of liberal globalization as we know it, there is also a unique opportunity to explore alternatives between this ailing hyperglobalization and the retrenchment to economic nationalism. Perhaps we can explore, too, new forms of allegiance, of community and of governance that are not simply going back to the nation-state on offer.

\section{Conclusion}

Rodrik's book is refreshingly critical and honest. It reflects years of thinking hard and writing eloquently about the risks posed by globalization in its current form. Risks that, as he warned many years ago, have materialized. Rodrik has also taken on his discipline for not engaging honestly with the public about the potential negative effects of trade liberalization, thus preventing a wider and more robust discussion on how to address the social and distributive concerns with trade. He is dismayed by the tendency of many economists to peddle ever

\footnotetext{
34 Ibid., 225; principle 7 reads: "Nondemocratic countries cannot count on the same rights and privileges in the international economic order as democracies."

${ }^{35}$ Ibid., 47.

${ }^{36}$ Ibid., 29.

37 Ibid., 47.
} 
increasing trade liberalization based on simplistic assumptions, even when they knew better. This, he argues, tended to set aside valid concerns, raised unwarranted expectations, reduced the scope of debate and policy proposals, and helped damage the credibility of the profession.

In our moment of crisis, when much of globalization and its institutions have been questioned, we see once again a knee-jerk reaction against this backlash. A reaction that seems to assume that things would be fine if we could only contain the backlash - be it the Trump administration trade wars or Brexit - by holding on to the institutions and arrangements that preceded it. Rodrik's work encourages us to resist that impulse by showing all that was wrong with the liberal globalization of the past three decades, whose effects and their dismissal are largely responsible for the current backlash. His work points in a different direction, one of reimagining and remaking the institutions of the global market, including slowing down its pace and refocusing on the greater welfare and prosperity that should animate its existence. As with any author, one may disagree with certain parts of his assumptions, analysis or conclusions. But Rodrik's highly original voice is essential to understanding our present conundrum and how we may chart a way out of it. He has certainly delivered what he promised: straight talk on trade. 


\section{A RESPONSE TO THE COMMENTS BY THOMAS, GALLAGHER, SHAFFER AND SANTOS \\ Dani Rodrik}

I am truly grateful for this wonderful and gracious set of comments on my book Straight Talk on Trade: Ideas for a Sane World Economy. An author cannot wish for more than this: to have his work taken seriously, and then elaborated or critiqued in light of further reflection. Kevin P. Gallagher, Alvaro Santos, Gregory Shaffer and Chantal Thomas do that and much more in relatively small amount of space. What follows are some quick responses and rejoinders to their rich arguments.

I begin with Kevin P. Gallagher's point that perhaps I have been too hard on economists. I happily accept his corrective! Indeed, many other social scientists were complicit in misreading the consequences of the type of globalization we had embarked upon. This is especially true of mainstream international relations theorists in political science. Typically, these scholars took their cue from economists when they assumed the overall gains were large and the losers could be treated as merely rent seekers in the political system. Even though they should have known better, they treated trade agreements as efficiency-enhancing arrangements instead of the political documents that they were.

In a recent lecture, Robert Keohane, one of the most distinguished scholars of international relations, was quite honest about the shared responsibility and engaged in some self-criticism: "Those of us who have not only analyzed globalization and the liberal order but also celebrated them share some responsibility for the rise of populism. We did not pay enough attention as capitalism hijacked globalization. Economic elites designed international institutions to serve their own interests and to create firmer links between themselves and governments. Ordinary people were left out." 75

As Keohane indicates, and as I argue in the book, the policies pushed by the US elite undermined what another political scientist, John Ruggie, called "embedded liberalism." Too many international relations scholars overlooked the consequences.

Alvaro Santos provides a deep and nuanced reading of the book and raises three important questions. First, he is skeptical about the project of "model diagnostics" or "model selection" I advocate for applied economists. I propose this approach as a way of moving from a position of relative agnosticism ("there are many contending models") to reasonable policy prescriptions ("the evidence indicates we can rule out these models while these other ones may well apply"). Being able to move down this path, Santos writes,

“... presupposes that there is a meta-level standpoint, free from the influence of method, from where we can choose.... The view of the utility of one or another model will be colored by one's own assumptions, that is, by one's own implicit or explicit meta model. And at that level, too, there will be competition and uncertainty."

\footnotetext{
${ }^{75}$ This is from the piece Keohane wrote jointly with Jeff D. Colgan in Foreign Affairs (see https://www.foreignaffairs.com/articles/world/2017-04-17/liberal-order-rigged). The article is based on Keohane's Warren and Anita Manshel Lecture in American Foreign Policy, delivered at Harvard University in December 2016.
} 
I do not necessarily disagree. I certainly do not want to underplay the difficulty of engaging in a model selection process that is truly "objective." But in my defense, I would point out that empirical analysis does in fact discipline this process, and does so in a somewhat nonideological manner. We have seen, for example, how empirical work on the labor market consequences of trade (considerable) or the growth effects of financial globalization (not much) has moved the discipline's priors. Ideology plays a role in shaping the questions we ask and the priors we take on-but it is not everything. Objective facts do exist and they do matter. Perhaps we can be more optimistic with respect to economics than legal scholarship here because positive, empirical analysis — did $X$ cause $Y$ ? — plays such a larger role in economics.

Second, Santos wonders about my nation-state-centric approach to the determination of standards. I draw here a distinction between a country setting its own standards (which I say is justified) and a country imposing its own standards on others (not justified). As Santos rightly observes, the distinction may not matter a whole lot in practice. If the United States imposes its own fishing standards on all imports, Malaysia has little choice but to adopt the US standard—if it wants to sell in the US market.

I am not sure this is any different from the United States applying, say, the same health and safety standards to imports as it does to domestic production. Chinese exporters are not allowed to sell toys in the United States that contain more lead than what domestic regulations allow. We take this as perfectly normal and do not challenge it, even though it certainly constrains China's trading options.

None of this is to say that international harmonization of standards is necessarily bad or should not be attempted. My worry about international harmonization is that it gives trade interestsexporters, multinationals, pharma companies - too much say. Ultimately, regulatory standards have to be politically legitimized, and the international sphere falls far short of what is required with respect to political accountability compared to the domestic sphere.

This leads to Santos's third note of skepticism. "I profess certain ambivalence about the nationstate," he writes:

"At a time where the globalization backlash throws into question the assumptions and institutions of liberal globalization as we know it, there is also a unique opportunity to explore alternatives between this ailing hyperglobalization and the retrenchment to economic nationalism. Perhaps we can also explore new forms of allegiance, of community and of governance that are not simply going back to the nation-state on offer."

I am in fact very sympathetic to this line of thinking. Even though my book does call for a reinvigoration of the nation-state, I am not averse to experimentation with the goal of creating new forms of political allegiance. At the same time, we should not overlook that the main proponents of such a project in recent decades have been precisely the hyperglobalizers, for whom transnational allegiances have provided a convenient cover for failing to live up to their local responsibilities.

Gregory Shaffer relates my work to that of legal realists: "To develop a pragmatic international economic law," he writes, "Rodrik's insight should be combined with the parallel ideas of the legal realists concerning the dangers of simple economic models that have been embedded in 
legal doctrine." Shaffer discusses a number of aspects of legal realism that indeed closely parallel my own thinking on economic models and institutional design. I confess this is a new area for me, but look forward to learning more about it from Shaffer and others.

Chantal Thomas poses two questions: First, have global value chains (GVCs) and the internationalization of production they entail made national economic governance no longer "realistically possible or effective"? Second, am I too pessimistic about the prospects for industrialization in developing nations, in view of the existing flexibilities in trade agreements and the possibilities of South-South trade? I will take them together, as they are closely related.

My sense is that we greatly exaggerate both the role that GVCs have played so far in developing countries' trade and their potential contribution to these countries' development. In a paper I have just finished, ${ }^{76}$ I have looked at these questions and come out with largely pessimistic conclusions. First, the expansion of GVCs seems to have ground to a halt in recent years. Second, developing-country participation in GVCs, and indeed in world trade in general, has remained quite limited, with the notable exception of certain Asian countries. Third, and perhaps most worryingly, the domestic employment consequences of recent trade trends have been quite disappointing. The job intensity of exports has steadily declined since around 2001 in not just advanced but also developing nations. This trend is not very surprising for the advanced nations, where skill-biased technological change has been ubiquitous and the leading cause of declining employment shares in manufacturing industries. It is more puzzling and disappointing in lowincome countries, where one would have expected to see the beneficial employment consequences of diversification out of natural resource exports and transition into labor-intensive manufactures.

GVCs have of course made inroads in developing countries in manufacturing, services and agriculture. Many of the exports of developing countries are channeled through GVCs, which also act as conduits for new technologies. But in most developing countries, and certainly the poorest ones, sectors and activities touched by GVCs remain a very small part of the domestic economy. New capabilities and productive employment remain limited to a tiny sliver of globally integrated firms.

These trends suggest that there remains a substantial role still for national economic governance. The key challenge is to disseminate throughout the rest of the economy the capabilities already in place in the most advanced parts of the productive sector. We can call this a process of domestic productive integration to accompany the usual process of international economic integration. In addition to improving fundamentals - human capital and governancegovernments require more proactive policies of government-business collaboration targeted at strengthening the connections between highly productive global firms, potential local suppliers and the domestic labor force. The principles governing such proactive policies have been laid out in discussions of "new industrial policy," with the important proviso that the policies in question would not concentrate exclusively on manufacturing.

\footnotetext{
${ }^{76}$ See Dani Rodrik, "New Technologies, Global Value Chains, and Developing Economies," Pathways for Prosperity Commission, University of Oxford, September 2018, https://drodrik.scholar.harvard.edu/publications/new-technologies-global-value-chains-and-developing-economies.
} 